\title{
PENGGUNAAN BAHASA PADA AKUN \\ INSTAGRAM LAMBE TURAH: ANALISIS WACANA KRITIS
}

\section{(Language Use on Lambe Turah Instagram: Critical Discussion Analysis)}

\author{
Andi Indah Yulianti \\ Mahasiswa Magister Ilmu Linguistik FIB Universitas Brawijaya \\ Pos-el: andiindahyulianti@gmail.com
}

\begin{abstract}
The purpose of this study is to describe the aspects of language, the relationship between Lambe Turah ideology with the linguistic aspects that are produced and describe the hegemony of Lambe Turah with the social situation underlying the language aspect used in representing the characters and news themes in Lambe Turah account. The method used in this paper is descriptive qualitative method with the approach of critical discourse analysis of three dimensional model from Norman Fairclough. The results indicate that the linguistic aspect of diction, sentence use, and source selection in the direct quotes used by Lambe Turah has placed the characters in their content as negative representations. In terms of the discourse aspect, Lambe Turah which has many followers and close to various circles, has access to pick up the news that if needed a lot of responses from the community to be handled immediately. While from the aspect of social practice Lambe Turah is very influential in influencing the opinion of Indonesian society.
\end{abstract}

Keywords: analysis of critical discourse; language; social media.

\begin{abstract}
Abstrak
Tujuan dari penelitian ini adalah mendeskripsikan aspek-aspek kebahasaan, hubungan antara ideologi Lambe Turah dengan aspek kebahasaan yang dihasilkan dan mendeskripsikan hegemoni Lambe Turah dengan situasi sosial yang melatarbelakangi aspek kebahasaan yang digunakan dalam merepresentasikan tokoh dan tema pemberitaan dalam akun tersebut. Metode yang digunakan dalam tulisan ini adalah metode deskriptif kualitatif dengan pendekatan analisis wacana kritis model tiga dimensi Norman Fairclough.Hasil penelitian menunjukkan bahwa aspek kebahasaan berupa diksi, penggunaan kalimat, dan pemilihan sumber dalam kutipan langsung yang digunakan Lambe Turah telah menempatkan tokoh-tokoh dalam isi pemberitaannya sebagai representasi yang negatif. Dari segi aspek kewacanaan, Lambe Turah yang memiliki banyak pengikut dan dekat dengan berbagai kalangan, memiliki akses untuk mengangkat berita-berita yang sekiranya membutuhkan banyak tanggapan dari masyarakat agar segera ditangani.Sedangkan dari aspek praktik sosial Lambe Turah sangat berperan dalam mempengaruhi opini masyarakat Indonesia.
\end{abstract}

Kata kunci: analisis wacana kritis; bahasa; media sosial. 


\section{PENDAHULUAN}

Jagad hiburan tanah air tidak pernah lepas dari berita, informasi maupun gosip atau yang biasa disebut infotainment. Istilah infotainment sudah menjamur di Indonesia sejak bermunculan program acara di media televisi berupa tayangan-tayangan yang membahas tentang gosip dan kehidupan artis. Jika dilihat dari arti harfiahnya, kata infotainment merujuk pada dua kata yaitu information (informasi) dan entertainment (hiburan) yang artinya kurang lebih informasi mengenai dunia hiburan. Di Amerika Serikat, makna infotainment berbeda dengan apa yang kita pahami selama ini. Terminologi infotainment merujuk pada berita yang disampaikan sebagai hiburan (Nastiti dalam

https://www.scribd.com/doc/91799496/Mengup as-Tayangan-Infotainment-dari KerangkaIndustri-Media). Sedangkan di Indonesia, istilah infotainment lebih merujuk kepada informasi tentang hiburan yang sifatnya ringan dan sensasional. Berita yang sebagian besar isinya mengupas kehidupan selebritas dan identik dengan acara gosip. Singkatnya, infotainment adalah salah satu jenis penggelembungan bahasa yang kemudian populer untuk istilah berita ringan.

\section{Berita infotainmen biasanya berisi} tentang berita-berita selebritas baik dalam maupun luar negeri. Pada dasarnya, berita infotainment tidak hanya berisi berita-berita gosip, tetapi juga memberitakan berita-berita baik mengenai publik figur. Tidak semua artis atau publik figur menginginkan ketenaran melalui jalan instan. Tapi, tidak sedikit pula artis rela mengumbar kehidupan pribadinya demi menjadi bahan pemberitaan bagi banyak media. Sang artis, entah sengaja atau tidak memberikan akses kepada media-media atau akun-akun gosip untuk mengetahui kehidupan pribadi mereka baik itu dalam bentuk foto, video atau curhatan di media sosial. Beritaberita gosip tersebut menjadi daya tarik tersendiri bagi media sehingga menarik minat pembaca/penontonnya. Meskipun demikian, tidak sedikit pandangan buruk masyarakat terhadap berita infotainment karena mereka beranggapan bahwa berita infotainment adalah berita yang tidak bermutu dan tidak mendidik.

Melihat animo masyarakat yang begitu besar terhadap informasi hiburan, maka bermunculan tabloid, acara, dan akun media sosial yang khusus membahas gossip dan kehidupan artis. Salah satu akun yang sedang booming akhir-akhir ini adalah akun Instagram (IG) Lambe Turah. Lambe Turah lebih memilih Instagram sebagai platform medianya, karena Instagram lebih efektif dalam mengunggah foto dan tidak memiliki batasan caption sehingga tidak ada batasan kata dalam penulisan berita. Selain itu Instagram sudah menjadi media sosial yang digunakan hampir seluruh masyarakat Indonesia.Bisa dikatakan bahwa akun IG Lambe Turah merupakan akun gosip yang memiliki follower/pengikut banyak, dan sebagian dari pengikutnya adalah kalangan selebritas.

Gosip maupun berita yang dihadirkan akun IG Lambe Turah selalu anyar dan menjadi rujukan tayangan dan berita infotainment di 
tanah air. Hal ini menimbulkan rasa penasaran baik di kalangan masyarakat maupun kalangan selebritas siapa mengenai administrator di baliknya. Namun sampai sekarang belum diketahui siapa yang menayangkan berita-berita tersebut dan masih menjadi tanda tanya di kalangan pengguna Instagram dan selebritas. Berita yang anyar disertai dengan bukti video atau foto, dan caption yang seringkali menggelitik, membuat akun IG ini sangat terkenal dan menjadi akun dengan pengikut terbanyak. Selain itu, penyajian berita yang cepat dan up to date dan seringkali menjadi referensi akun gossip lain juga membuat akun ini memiliki banyak penggemar.

Bahasa pada foto atau video yang diunggah akun IG Lambe Turah tidak lepas dari kemampuan admin dalam mengolah kata-kata. Bahasa tulis yang digunakan terkesan lucu, namun seringkali cenderung sinis, sarkas, dan pedas. Sebagaimana akun yang berada di media sosial, akun ini lebih banyak menggunakan bahasa-bahasa nonformal untuk berinteraksi dengan pengikutnya. Interaksi dengan kata-kata berbanding lurus dengan kemampuan seseorang dalam berbicara, karena interaksi dalam bentuk verbal pada media jejaring sosial menjadi katakata vital yang akan dipahami publik dengan persepsi berbeda.

Penulis mencoba menganalisis sejauh mana penggunaan bahasa dalam berita-berita yang disajikan akun IG Lambe Turah sebagai sebuah wacana. Karena menurut Searle (dalam Stephen W. L., 2009:163), teori kemampuan berbicara dirancang untuk membantu kita memahami

bagaimana

manusia menyempurnakan hal dengan kata-kata. Searle menjelaskan bahwa di setiap pernyataan yang diucapkan menyelesaikan beberapa hal di antaranya: (1) akan menghasilkan sebuah wacana yang disebut dengan aksi terungkap (utterance act), yaitu sebuah penyebutan katakata dalam kalimat, (2) sedang menegaskan sesuatu tentang dunia atau melakukan sebuah aksi usulan (proposional act), baik meyakininya sebagai kebenaran maupun mencoba supaya orang lain supaya memercayainya, memenuhi sebuah niat, yaitu aksi berkehendak (illocutionary act).

Teori Fairclough yang digunakan dalam penelitian ini akan berusaha mengungkap bagaimana bahasa menyebabkan kelompok sosial yang ada bertarung dan mengajukan ideologinya masing-masing. Analisis Wacana melihat pemakaian bahasa tutur dan tulisan sebagai praktik sosial. Praktik sosial dalam analisis wacana dipandang menyebabkan hubungan yang saling berkaitan antara peristiwa yang bersifat melepaskan diri dari dari sebuah realitas, dan struktur sosial. Dalam jejaring sosial, semua kata-kata yang ditulis akan memaknai maksud pernyataan yang ingin disampaikan. Dari uraian latar belakang, maka masalah yang akan diangkat adalah bagaimanakah analisis wacana kritis penggunaan bahasa pada akun Instagram Lambe Turah sebagai akun informasi dan gosip selebritas. Penelitian ini dilakukan dengan tujuan untuk mengetahui analisis wacana kritis penggunaan bahasa-bahasa pada akun Instagram 
Lambe Turah sebagai akun informasi dan gosip selebritas.

\section{TEORI}

\section{ANALISIS WACANA KRITIS}

Awal perkembangan Analisis Wacana Kritis (AWK) dikemukakan oleh Van Dijk pada tahun 1970-an. Analisis ini mendapat pengaruh teori linguistik kritis, teori sosial kritis Frankfurt, dan pascastrukturalisme yang berkembang di Perancis. Analisis adalah sebuah upaya atau proses memberi penjelasan dari sebuah teks (realitas sosial) yang akan atau sedang dikaji yang kecenderungannya mempunyai tujuan tertentu untuk memperoleh apa yang diinginkan, atau singkatnya, dalam sebuah konteks harus disadari akan adanya kepentingan. Kridalaksana (dalam Darma 2009: 69) membahas bahwa wacana adalah satuan bahasa terlengkap dalam hirarki gramatikal tertinggi dan merupakan satuan gramatikal yang tertinggi atau terbesar. Jadi, wacana adalah unit linguistik yang lebih besar dari kalimat atau klausa. Di dalam sebuah analisis wacana, wacana tidak hanya dipahami sebagai objek studi bahasa, walaupun memang AWK menggunakan bahasa dalam teks yang dianalisis, namun bahasa yang dianalisis dalam AWK juga berhubungan dengan konteks. Konteks di sini berarti bahasa yang dipakai untuk tujuan tertentu termasuk di dalamnya praktik kekuasaan, senada dengan Darma (2009: 32) yang menyatakan bahwa analisis wacana kritis melihat bahasa sebagai fakta penting, yaitu bagaimana bahasa digunakan untuk melihat ketimpangan-ketimpangan dalam masyarakat.

Eriyanto (2001: 31) berpendapat bahwa AWK lebih mementingkan aspek kualitatif dari pada kuantitatif. AWK lebih menekankan perhatiannya pada pemaknaan teks ketimbang penjumlahan unit kategori seperti dalam analisis isi. Dasar AWK adalah interpretatif yang mengandalkan interpretasi dan penfsiran peneliti, sementara analisis isi kuantitatif hanya dapat digunakan untuk membedah muatan teks komunikasi yang bersifat nyata, sedangkan AWK lebih memfokuskan pada pesan yang tersembunyi.

Fairclough dan Wodak melihat AWK sebagai pemakaian bahasa baik lisan maupun lisan sebagia bentuk praktik sosial. Fairclough juga berpendapat bahwa konsep yang dia bentuk menitik beratkan tiga fungsi yaitu fungsi representasi, relasi dan identitas. Kedua, praktik wacana meliputi cara-cara para pekerja media memproduksi teks, dan ketiga adalah praktik sosial-budaya yang meliputi ekonomi, politik dan budaya yang juga memengaruhi situasi media dan wacananya. Dalam AWK, analisis wacana digunakan untuk meneliti ideologi yang tersembunyi di dalam teks. Eriyanto (2001:223) berpendapat bahwa analisis wacana dapat digunakan untuk membongkar kuasa yang ada dalam setiap proses bahasa, batasan-batasan apa yang menjadi wacana, perspektif, dan topik apa yang dibicarakan. Lebih lanjut Eriyanto (2001:224) menyatakan bahwa wacana tidak hanya menganalisis kebenaran suatu teks dari segi struktur menurut kaidah sintaksis dan 
semantik tetapi juga menganalisis suatu pernyataan dalam teks lewat konteks sosialnya. Senada dengan Eriyanto, Badara (2012:21) menyatakan bahwa di balik sebuah wacana terdapat makna dan citra yang diinginkan serta kepentingan yang sedang diperjuangkan. Oleh karena itu, bahasa selalu terlibat dalam hubungan kekuasaan dan sebagai representasi tindakan yang terjadi di dalam masyarakat. Menurut Darma (2009: 49), Analisis Wacana Kritis adalah sebuah upaya untuk proses penguraian untuk memberi penjelasan dari sebuah teks atau realitas sosial dari suatu kelompok atau seseorang yang kecenderungan memiliki tujuan tertentu untuk mencapai tujuan yang diinginkan.

Analisis wacana model Fairclough atau yang lebih dikenal sebagai analisis wacana tiga dimensi, menganalisis tataran wacana dalam bentuk, 1) teks (textual), 2) praktik kewacanaan yang melibatkan pemroduksian dan pengkonsumsian teks (discourse practice), dan 3) praktik sosial (social cultural prctice) (Fairclough dalam Firdaus, 2011: 7).

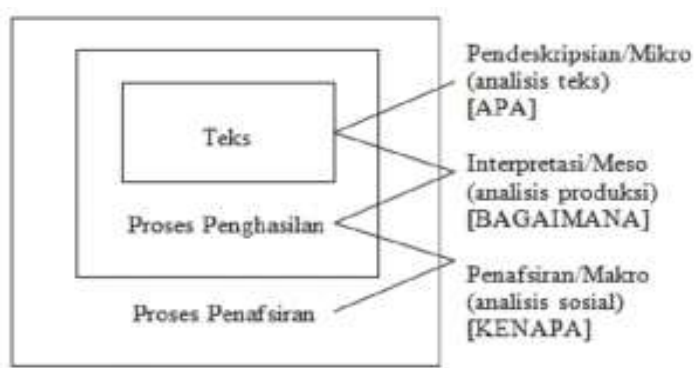

Bentuk pertama analisis model Fairclough adalah analisis dimensi teks (micro level) yang meliputi bentuk-bentuk tradisional analisis linguistik, yang meliputi analisis kosakata dan semantik, tata bahasa kalimat dan unit-unit yang lebih kecil, sistem suara (fonologi) dan tulisan (Fairclough, 1995: 57). Bentuk pertama analisis wacana kritis ini adalah menganalisis teks dengan cermat dan fokus supaya dapat memperoleh data yang dapat menggambarkan representasi teks. Secara detail, aspek yang dianalisis adalah garis besar atau isi teks, lokasi, dan sikap dan tindakan tokoh dan seterusnya.

Bentuk kedua analisis dalam kerangka analisis wacana kritis Fairclough adalah dimensi kewacanaan (discourse practice) atau meso level. Dalam analisis ini, penafsiran dilakukan terhadap pemrosesan wacana yang meliputi aspek penghasilan, penyebaran, dan penggunaan teks. Beberapa dari aspek-aspek itu memiliki karakter yang lebih institusional. Berkenaan dengan proses-proses institusional, Fairclough merujuk rutinitas institusi seperti prosedurprosedur editor yang dilibatkan dalam penghasilan teks-teks media. Dengan kata lain, analisis ini terfokus pada produksi teks dan konsumsi teks. Sedangkan bentuk ketiga adalah analisis praktik sosiobudaya media dalam analisis wacana kritis (macro level). Analisis didasarkan pada pendapat bahwa konteks sosial yang ada di luar media sesungguhnya memenuhi bagaimana wacana yang ada di dalam media. Ruang redaksi atau wartawan bukanlah bidang atau ruang kosong yang steril, tetapi juga sangat ditentukan oleh faktor-faktor di luar media itu sendiri. Fairclough (1992:67) menyatakan bahwa praktik sosial memiliki berbagai orientasi, seperti orientasi ekonomi, politik, sosial, budaya, ideologi dan sebagainya dan wacana adalah gambaran dari berbagai 
orientasi tersebut. Dapat disimpulkan bahwa analisis dimensi praktik sosial merujuk pada usaha menjelaskan persoalan yang berkaita dengan nilai, kepercayaan, ideologi, filosofi, budaya yang terdapat dalam wacana. Simpulannya adalah, AWK menganalisis bahasa bukan hanya aspek kebahasaannya saja, tetapi juga menghubungkan konteks bahasa yang dipakai untuk tujuan tertentu karena analisis wacana bisa melihat makna yang tersembunyi dari suatu teks.

\section{CIRI-CIRI ANALISIS WACANA KRITIS}

Akbar (dalam Bungin, 2003: 154), menyebutkan ciri-ciri analisis kritis: Pertama, aliran kritis lebih menekankan pada unsur-unsur filosofis komunikasi, unsur-unsur tersebut mencakup ideologi apa di balik sebuah media. Kedua, aliran kritis melihat struktur sosial sebagai konteks yang sangat menentukan realitas, proses, dan dinamika komunikasi manusia, khususnya (termasuk komunikasi massa). Ketiga, aliran kritis lebih memusatkan perhatiannya pada siapa yang mengendalikan komunikasi. Aliran ini beranggapan bahwa komunikasi hanya dimanfaatkan oleh kelas yang berkuasa, baik untuk mempertahankan kekuasaanya maupun untuk merepresi pihakpihak yang menentangnya. Keempat, aliran kritis sangat yakin dengan anggapan bahwa teori komunikasi manusia, khususnya teori komunikasi massa, tidak mungkin dapat menjelaskan realitas secara utuh dan kritis apabila ia mengabaikan teori-teori masyarakat.
Oleh karena itu, teori komunikasi massa harus selalu berdampingan dengan teori-teori sosial.

\section{SEJARAH INFOTAINMENT DI} INDONESIA

Perkembangan media ditandai dengan munculnya fenomena jejaring sosial atau social network atau sosial media. Ninda (dalam Pathia, 2014:2) menyatakan bahwa media sosial adalah fitur berbasis laman yang membentuk jaringan dan memungkinkan orang untuk berinteraksi dalam sebuah interaksi. Disebut jejaring sosial karena media ini meyediakan media komunikasi bukan hanya di dunia nyata namun juga di dunia maya. Menurut Devi (dalam http://paramithadevi-

degreece.blogspot.co.id/2010/06/infortainment. html) infotainment jika dilihat dari kemunculannya sudah ada sejak tahun 1929. Akan tetapi pada tahun itu, pemberitaan mengenai artis dan film melalui media cetak dan majalah yang pertama kali terbit di Jakarta dan membahas masalah tersebut adalah Majalah 'Doenia Film'. Infotainment baru muncul setelah adanya kebebasan pers. Memasuki era reformasi, di mana pers tidak membutuhkan surat ijin lagi, banyak pengusaha yang mulai merekrut wartawan-wartawan dunia hiburan. Para pengusaha mulai menggunakan wartawan hiburan dalam mencari informasi tentang selebritas tanah air agar dapat memperoleh keuntungan besar. Program acara infotainment dipopulerkan oleh Ilham Bintang pada tahun 1994 melalui tayangan Buletin Sinetron di TVRI, kemudian setelah itu lahirlah Cek dan Ricek, Halo Selebriti, dan Kroscek di sejumlah 
televisi swasta sampai akhirnya menjamur di hampir semua stasiun televisi.

Nugroho dkk (2005:5) menyatakan bahwa infotainment adalah informasi yang ringan dan aktual seputar dunia selebritas dan orang-orang terkenal yang dikemas dalam dalam bentuk hiburan. Lebih lanjut, Nugroho menyatakan bahwa terlepas dari akar kelahirannya di Barat, di mana infotainment sebenarnya berarti 'informasi yang disajikan sebagai hiburan', di Indonesia, istilah infotainment sudah berubah arti menjadi informasi dunia hiburan yang kemudian lebih spesifik lagi menjadi informasi mengenai kehidupan pribadi para artis di dunia hiburan. Seiring dengan perkembangan jaman, infotainment kini tidak hanya berada di media cetak, namun telah merambah ke layar kaca, dan media online.

Jenis jurnalisme baru ditandai dengan kemunculan internet. Pemberitaan online biasanya didominasi oleh situs-situs yang merupakan 'edisi online' seperti detikcom, merdeka,viva.co.id, dan lain-lain. Syamsul (2012: 33-34) menyatakan bahwa media online memiliki beberapa karakteristik dan keunggulan bila dibandingkan dengan media cetak dan eletronik, yaitu:

1. Multimedia: dapat menyajikan atau memuat berita dan informasi dalam bentuk teks, audio, video, dan grafis secara bersamaan.

2. Aktualitas: info yang disajikan aktual karea kemudahan dan kecepatan penyajian.
3. Cepat: begitu berita diposting, langsung bisa diakses semua orang.

4. Update: pembaruan informasi dapat dilakukan dengan cepat, baik dari segi konten maupun redaksional.

5. Kapasitas luas: halaman web bisa menampung panjang naskah.

6. Fleksibilitas: pemuatan dan editing naskah bisa kapan dan di mana saja.

7. Luas: menjangkau seluruh dunia yang memiliki akses internet.

8. Interaktif: mempunyai fasilitas kolom komentar dan chat room.

9. Terdokumentasi: informasi tersimpan dan bank data atau arsip dapat ditemukan melalui tautan (link) atau fasilitas "cari" (search).

10. Hyperlinked: terhubung dengan sumber lain yang berkaitan dengan informasi.

Keunggulan-keunggulan dan karakteristik yang dimiliki oleh media online menjadikannya lebih banyak digunakan masyarakat karena fiturfiturnya memudahkan masyarakat dalam berkomunikasi.

Syamsul (2012: 103) menyatakan bahwa Instagram, Facebook, dan Twitter menjadi media interaksi paling efektif yang sering digunakan sebagai alat komunikasi, sosialisasi, dan promosi. Menurut Wikipedia, Instagram merupakan sebuah aplikasi media sosial yang memungkinkan penggunanya mengambil foto, menerapkan filter digital, lalu mengunggahnya ke dalam akun pribadinya lalu membagikannya ke berbagai layanan jejaring sosial. 
Menurut Fathurrohman(2014) dalam http://blogpenemu.blogspot.id./2014/10/penemu -pendiri-instagram-kevinsystrom dan-mikekrieger.html, Instagram berasal dari kata 'insta' dan 'gram'. Kata 'insta' berasal dari kata 'instan', seperti kamera Polaroid yang pada masanya lebih dikenal dengan 'foto instan'. Kata 'gram' berasal dari kata 'telegram' yang cara kerjanya mengirimkan informasi kepada orang lain dengan cepat. Sama halnya dengan Instagram yang dapat mengunggah foto dengan menggunakan jaringan internet sehingga infromasi yang ingin disampaikan dapat diterima dengan cepat. Aplikasi Instagram dibuat oleh dua orang alumnus Universitas Stanford bernama Kevin Systrom dan Mike Krieger yang melihat bahwa kebutuhan foto dalam lima tahun ke depan akan sangat berkembang karena semua orang akan mempunyai kamera dalam ponsel pintar mereka. Sejak berdiri kemudian diakuisisi Facebook, kesuksesan Instagram terus menanjak dan saat ini memiliki 400 juta pengguna di seluruh dunia.

Sekarang, hampir seluruh pesohor menggunakan media sosial Instagram sebagai ajang promosi dan sebagai alat mendekatkan diri dan berinteraksi kepada para penggemar. Interaksi antara pengelola suatu akun media sosial dengan pengikut/masyarakat menjadi salah satu hal harus diperhatikan karena citra suatu akun figur pesohor sangat ditentukan oleh administratornya. Dengan kata lain, administrator suatu akun media sosial merupakan bentuk lain dari humas atau public relation dari pesohor tersebut. Karena selebritas rata-rata memiliki akun Instagram, maka otomatis bermunculan pula akun-akun fanbase (penggemar) dan akun-akun gosip.

\section{KODE ETIK MEDIA SOSIAL}

Saat ini banyak sekali media sosial, sehingga memudahkan orang-orang untuk menuangkan pikiran dan pendapat mereka. Tetapi terdapat batas-batas norma dalam menulis di media sosial, agar tidak terjadi penyalahgunaan dan merugikan pihak-pihak lain. Ujaran kebencian akan berdampak hukum. Merundung, menghujat, menghina, atau membuka aib orang lain di media sosial adalah haram hukumnya. Apalagi dengan dikeluarkannya edaran Kapolri Badrodin Haiti mengenai hate speech bernomor SE/06/X/2015, tentu menjadi rambu-rambu bagi pengguna sosial media.

Dalam bersosial media mengeluarkan opini terhadap hal-hal yang ingin dikomentari merupakan hal yang tidak dilarang, asal opini berdasarkan fakta dan data yang ada. Dalam hal ini bila beropini negatif pada seseorang kemungkin saja dapat dilaporkan dengan UU ITE Pasal 27 ayat 3 tentang pencemaran nama baik di dunia maya. Naresyach (2014), dalam http://softskillarrighy.blogspot.co.id/2014/10/eti ka-dan-kode-etik-menulis-di-media.html menyatakan bahwa di dalam menulis sebuah berita, artikel ataupun pendapat, sebaiknya menggunakan bahasa yang sopan. Internet dapat diakses oleh seluruh kalangan masyarakat, dan tentunya tulisan tersebut juga akan dibaca oleh seluruh kalangan masyarakat di seluruh dunia. 
Jadi, jika tidak menggunakan bahasa yang baik, benar dan sopan, cara pandang orang lain kepada penulis tentu akan berbeda dan mungkin akan berdampak langsung kepada pribadi serta lingkungan penulis sendiri.

\section{METODE}

Penelitian ini menggunakan metode deskriptif kualitatif dengan pendekatan teori Analisis Wacana Kritis Norman Fairclough. Metode deskriptif kualitatif menurut Sudaryanto (1992:63) adalah pendekatan yang lebih menandai pada hasil penelitian yang bersangkutan dengan cara menandai cara penggunaan bahasa tahap demi tahap, langkah demi langkah. Pendekatan ini digunakan dengan maksud untuk memecahkan masalah yang sedang dihadapi oleh peneliti, yaitu faktor penyebab terjadinya kesinambungan wacana dan wujud kesinambungan wacana yang terdapat pada teks atau caption berita.

Data penelitian ini berupa'postingan' pada akun Instagram Lambe Turah selama tahun 2017 yang memuat pemberitaan tentang selebritas dan berita-berita lainnya. Data penelitian ini didapatkan dengan teknik dokumentasi. Teknik pengolahan data dibagi menjadi beberapa tahap:

1. mengumpulkan objek penelitian berupa postingan berita pada akun Instagram Lambe Turah,

2. memilah, menganalisis, dan mendeskripsikan elemen-elemen kebahasaan yang dimiliki setiap berita,
3. menganalisis dan membahas objek berdasarkan teori AWK, dan,

4. menyimpulkan hasil analisis.

\section{TEMUAN DAN PEMBAHASAN}

Untuk memahami kontruksi teks pemberitaan infotainment, maka dilakukan analisis teks terhadap postingan status akun @ lambe_turah. Adapun postingan tersebut adalah:

\section{DATA 1}

Analisis Mikro Pemberitaan "Waspada Komplotan Pencopet Handphone Kelas Kakap"

Postingan ini menceritakan tentang komplotan pencopet handphone yang sering melakukan aksinya di mal-mal Surabaya, Jogja, Semarang, Bali bahkan sampai ke luar negeri.Komplotan pencopet HP ini diketuai sepasang suami istri, dan salah satu korbannya adalah fotografer professional Rio Motret yang merupakan langganan para artis dalam setiap sesi pemotretan. 

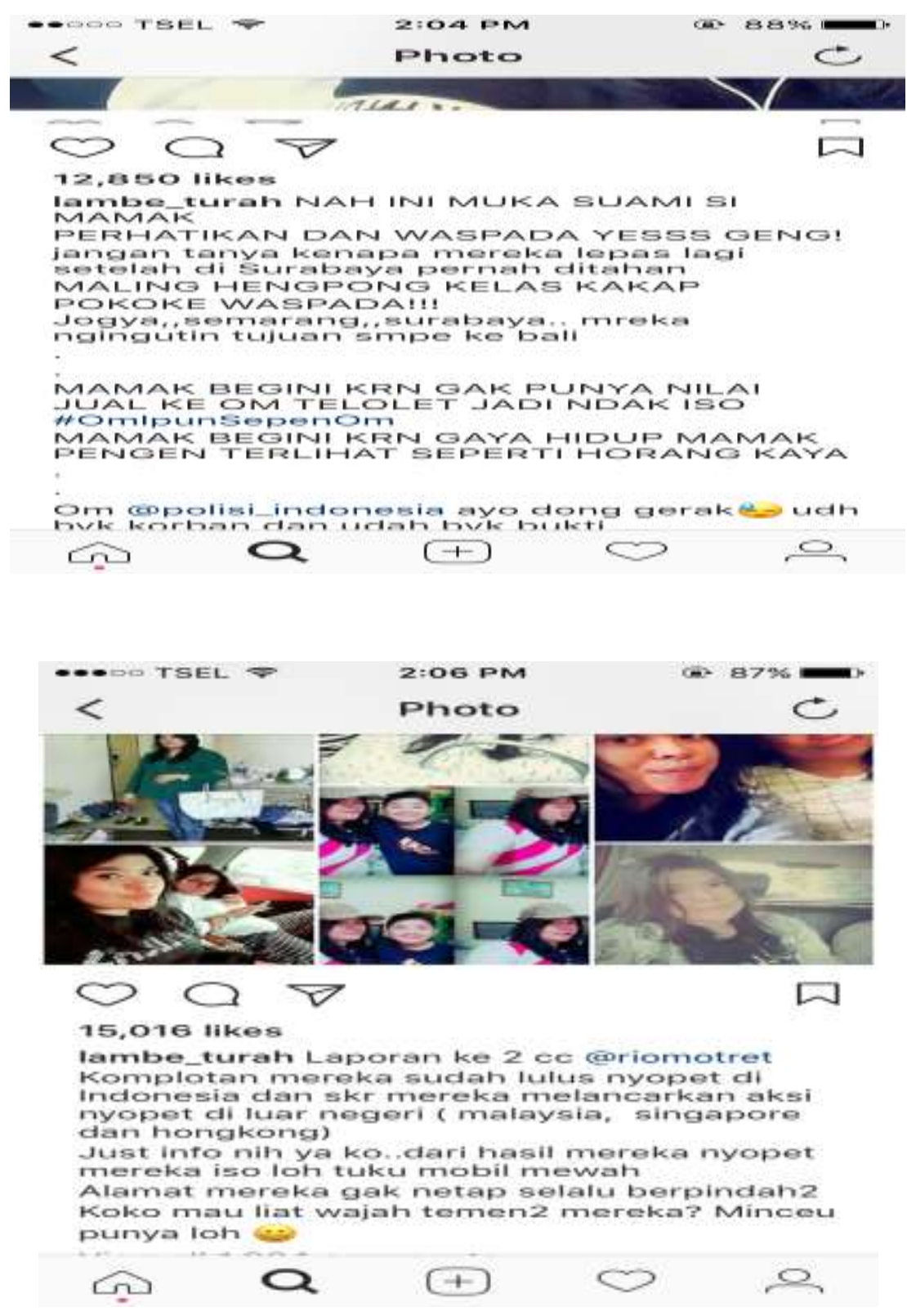

Dari postingan pemberitaan "Waspada Komplotan Pencopet Handphone Kelas Kakap”, terdapat dua hal yang dapat menandai representasi tema dan tokoh yang terlibat dalam pemberitaan tersebut, yaitu, pilihan leksikal dan penggunaan kalimat luas sebab akibat. Penggunaan leksikal "nyopet" dan "maling" mendominasi isi postingan tersebut. Sementara penggunaan kalimat sebab akibat telah menempatkan Rio Motret sebagai korban komplotan copet kelas kakap tersebut, isi berita yang merupakan sebuah bentuk laporan ke pada korban (Rio Motret) juga sangat valid karena ditambah dengan foto-foto pelaku pencopet. Di bawah ini adalah analisis dari aspek kebahasaan tersebut.

(1) Komplotan mereka sudah lulus nyopet di Indonesia dan skr (sekarang) mereka melancarkan aksi nyopet di luar negeri (Malaysia, Singapore, dan Hongkong).

(2) Just info nih ya ko... dari hasil mereka nyopet mereka iso loh tuku mobil mewah.

(3) Maling hengpong kelas kakap pokoknya waspada. 
Kata "nyopet" dan "maling" pada data (1), (2), dan (3) mempunyai makna sedikit berlainan. Kata "nyopet" berartimencuri (sesuatu yang sedang dipakai, uang di dalam saku, barang yang dijajakan, dan sebagainya) dengan cepat dan tangkas', memiliki makna mengambil barang-barang tanpa sepengetahuan orang lain namun dalam ukuran yang lebih kecil dan biasanya tidak selalu pada malam hari. Sedangkan kata maling bermakna leksikal mengambil milik orang lain secara sembunyisembunyi; (terutama yang mencuri pada malam hari).

(4) Mamak begini karena karena gaya hidup mamak pengen terlihat seperti horang kaya.

(5) Mamak begini karena gak punya nilai jual ke om telolet omjadi ndak iso \#OmIpunSepenOm (Om iPhone 7 Om)

(6) Om Polisi Indonesia ayo gerak dong, udah banyak korban dan udah banyak bukti.

Contoh data (4), (5), dan (6) merupakan contoh data pemanfaatan strategi linguistik yang berupa struktur kalimat.Kalimat luas pada data (4) dan (5) memiliki hubungan sebab akibat yang ditandai dengan frasa "mamak begini” di awal kalimat kemudian dikuti oleh anak kalimat. Data (6) memiliki hubungan sebab akibat yang dapat dilihat pada kalimat pertama yang merupakan ajakan dan diikuti oleh keterangan mengapa ajakan itu harus dilakukan pada kalimat setelahnya. Strategi linguistik yang digunakan pada bahasa akun Lambe Turah secara langsung sangat memprovokasi masyarakat untuk berhati-hati dan waspada. Selain memberi bukti konkret berupa foto, penggunaan bahasa akun ini juga menempatkan komplotan pencopet tersebut sebagai tokoh kriminal yang harus segera ditangkap.

\section{Analisis Makro Pemberitaan "Waspada} Komplotan Pencopet Handphone Kelas Kakap"

Tidak semua pihak menyambut positif status akun Lambe Turah sebagai akun gosip. Namun satu hal yang pasti, dengan lebih dari 2,6 juta pengikut dan tampaknya akan terus bertambah, Lambe Turah semakin menorehkan posisinya sebagai akun gosip paling berpengaruh dalam jagad dunia maya Indonesia.

\section{Hegemoni Akun Lambe Turah dalam Jagad Maya Indonesia}

Kasus pencurian yang menimpa Rio Motret menjadi titik balik dari pemberitaan komplotan pencopet handphone kelas kakap yang sangat lihai beraksi pada setiap tindakan kejahatannya. Setelah sekian lama beraksi akhirnya komplotan ini dapat diekspos tindak tanduknya oleh Lambe Turah. Dengan karakter postingan Lambe Turah yang sedikit nakal dan berani, bisa dipastikan bahwa para komplotan pencopet tersebut akan lebih berhati-hati dalam beraksi atau bahkan tidak lama lagi akan tertangkap setelah berkali-kali lolos.

Kebanyakan isu yang dibingkai dalam postingan Lambe Turah adalah perspektif baik versus jahat; atau dalam beberapa kasus, pendukung Lambe Turah melawan suporter artis/tokoh yang sedang dipermalukan atau tertimpa musibah. Jadi, bisa dikatakan bahwa jika seseorang mengalami suatu musibah, ketidakadilan, atau tindakan kurang menyenangkan dari seseorang, laporkan ke 
Lambe Turah, karena berita tersebut pasti akan diangkat dan akan mendapat respon dari khalayak, minimal, khalayak akan tahu apa yang sebenarnya terjadi, siapa yang menjadi korban dan siapa tokoh jahatnya.

\section{DATA 2}

\section{Analisis Mikro Pemberitaan "Kasus Kekerasan Mapala UII Yogyakarta"}

Postingan ini memberitakan tentang kekerasan berbuntut kematian yang menimpa tiga mahasiswa Mapala UII pada saat kegiatan di lereng gunung Lawu, Karanganyar. Kekerasan tersebut dilakukan kakak senior mereka yang merupakan panitia dari kegiatan tersebut.






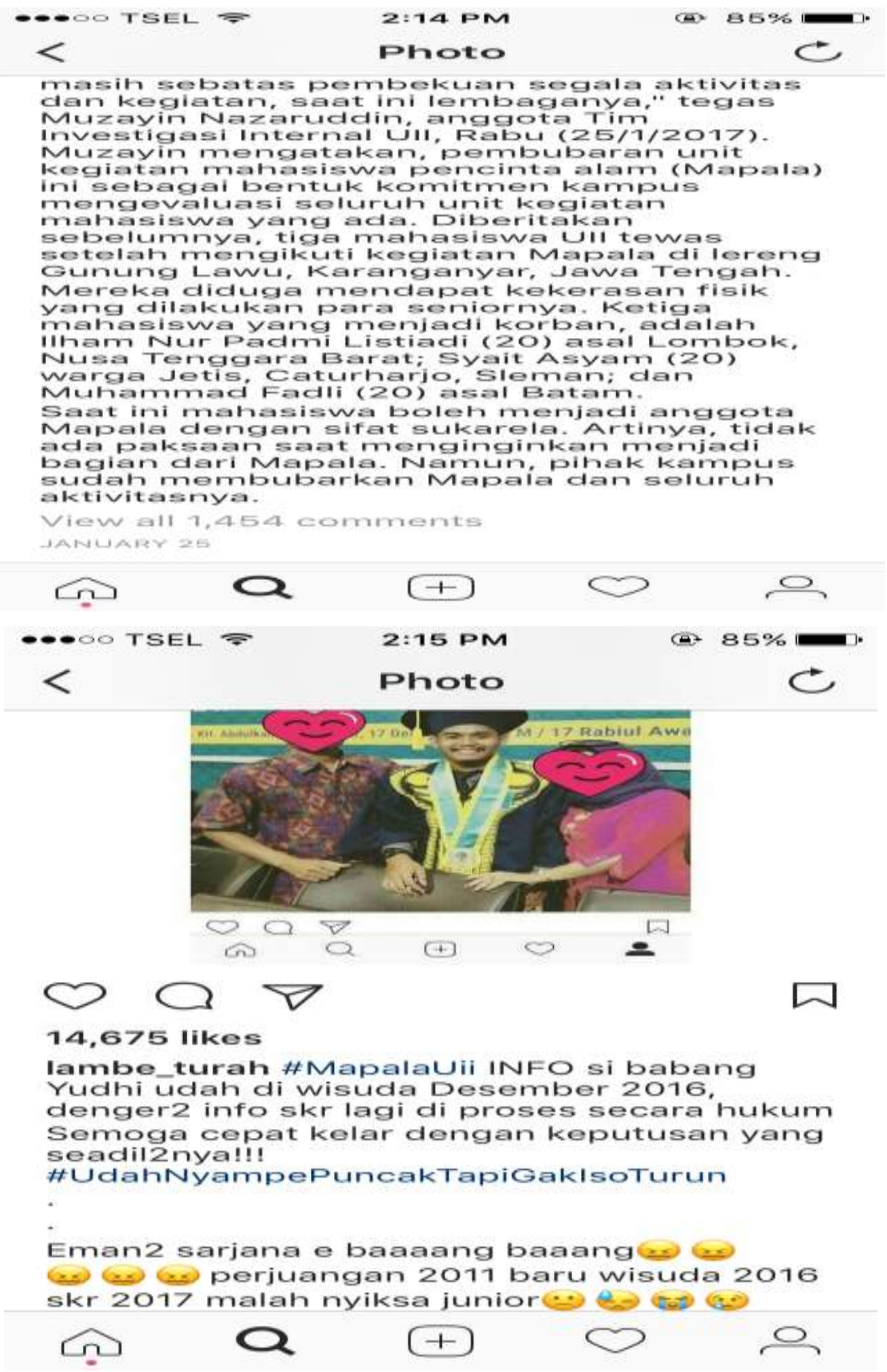

Dalam postingan di atas penulis akan menganalisis dari segi tekstual. Terdapat tiga alat yang menandai representasi tema dan tokoh yang terlibat dalam pemberitaan tersebut. Yaitu melalui pilihan leksikal, penggunaan kalimat luas sebab akibat, dan pemilihan sumber dalam kutipan langsung. Dari segi pilihan leksikal, penggunaan kata "pembubaran" lebih mendominasi dibandingkan dengan kata "pembekuan" yang menandai bahwa Lambe Turah memberi ketegasan akan status lembaga Mapala pada berita tersebut.

Untuk segi pemanfaatan kalimat luas dengan konstruksi sebab akibat telah 
menempatkan tokoh/pelaku kekerasan dalam representasi yang negatif karena diposisikan sebagai pihak yang mengakibatkan kematian tiga orang mahasiswa Mapala tersebut. Demikian pula halnya dengan pemilihan narasumber pada kutipan langsung, Lambe Turah lebih dominan menyuarakan keputusan tim investigasi UII atas kasus kekerasan ini, selain itu, Lambe Turah tidak lupa pula menyertakan postingan berisi foto pelaku dengan caption yang lumayan nyelekit. Di bawah ini adalah analisis dari segi tektual tersebut.

(1) Buntut kasus kematian tiga mahasiswa akibat aksi kekerasan, pihak kampus Universitas Islam Indonesia (UII) membubarkan unit lembaga Mahassiwa Pencinta Alam (Mapala) Unisi.

(2) Pembubaran ini berlaku sampai jangka waktu yang belum ditentukan.

(3) "Jadi lembaganya yang dibekukan, kalua kemarin masih sebatas pembekuan segala aktivitas dan kegiatan, saat ini lembaganya" tegas Muzayyin Nazaruddin, anggota Tim Investigasi UII.

(4) Muzayyin mengatakan pembubaran unit kegiatan Mahasiswa Pencinta Alam (Mapala) ini sebagai bentuk komitmen kampus mengevaluasi seluruh Unit Kegiatan Mahasiswa yang ada.

(5) Tidak ada paksaan saat menginginkan menjadi bagian Mapala, namum pihak kampus sudah membubarkan Mapala dan seluruh aktivitasnya.

Data (1) - (5) menandakan bahwa

untuk kasus ini, Lambe Turah memilih diksi "pembubaran/membubarkan" dan "dibekukan/pembekuan". Kedua diksi tersebut memiliki makna semantik yang berlainan pula. Secara semantik leksikal, makna kata "bubar/pembubaran" yang berarti ditiadakan (tentang perserikatan, kongsi, dan sebagainya), memiliki makna yang lebih tegas alih-alih makna kata "beku/dibekukan/pembekuan" yang berartitidak berlaku lagi, tetapi belum dicabut (tentang dewan, undang-undang, dan sebagainya).

Contoh data pemanfaatan strategi linguistik yang berupa struktur kalimat hubungan sebab akibat dapat lihat pada contoh kalimat di bawah ini:

(6) Buntut kasus kematian tiga mahasiswa akibat aksi kekerasan, pihak kampus Universitas Islam Indonesia (UII) membubarkan unit lembaga Mahassiwa Pencinta Alam (Mapala) Unisi.

Kalimat luas pada data (6) memiliki hubungan sebab-akibat yang ditandai dengan kata akibat pada kalimat pertama, dan penjelasan penyebab atas akibat tersebut pada kalimat kedua. Strategi bahasa yang digunakan oleh Lambe Turah dalam kontruksi kalimat sebab-akibat seperti ini menempatkan lembaga Mapala sebagai penyebab kekerasan yang terjadi dan menempatkan tiga mahasiswa dan kampus UII sebagai korban dan dirugikan atas polemik tersebut.

Selain aspek tekstual, Lambe Turah juga menyuarakan inspirasinya melalui kutipan langsung para tokoh yang menjadi narasumber. Berdasarkan data yang ada, Lambe Turah menyuarakan pendapat tim investigasi UII. Hal tersebut dapat dilihat dalam data berikut.

(7) "Jadi lembaganya yang dibekukan, kalua kemarin masih sebatas pembekuan segala aktivitas dan kegiatan, saat ini lembaganya" tegas Muzayyin Nazaruddin, anggota Tim Investigasi UII. 
Dari contoh di atas, dapat diketahui bahwa Lambe Turah memilih narasumber yang lebih mendukung pembubaran lembaga Mapala. Lambe Turah tidak memasukkan opini dari mahasiswa lain sehingga pemberitaan lebih berimbang. Isi wacana yang disampaikan melalui kutipan langsung tersebut juga sangat mendukung UII dan pihak berwajib untuk segera menindak pelaku terhadap ketiga mahasiswa yang menjadi korban kekerasan tersebut. Pada postingan terakhir, seperti ciri khas Lambe Turah pada umumnya, foto salah seorang pelaku ditampilkan dan diberi caption yang cukup lucu dan antiklimaks.

\section{Analisis Makro Pemberitaan "Kasus}

Kekerasan Mahasiswa Mapala UII Yogyakarta"

Sudah 36 kali acara diksar Mapala diselenggarakan oleh anggota Mapala UII setiap tahun dan tidak pernah ada korban jiwa. Namun, insiden memilukan terjadi setelah kegiatan diksar ke-37 di dusun Tlogodringo, desa Gandasuli, Kecamatan Tawangmangu, Karanganyar, Jawa Tengah.Peristiwa tersebut memperlihatkan bahwa pendidikan di tanah air masih belum lepas dari deraan fisik, yang diduga menjadi penyebab kematian ketiga korban. Ada sejumlah luka ditemukan di tubuh korban. Namun, sebagian peserta membantah ada penganiayaan yang mereka alami selama mengikuti diksar.

Pemberitaan tentang kekerasan yang berujung kematian yang menimpa ketiga mahasiswa tersebut turut mengusik akun Lambe Turah yang biasanya lebih sering mengangkat berita-berita hiburan dan gossip artis tanah air. Postingan-postingan tentang kasus ini sukses membuat pengikutnya berkomentar, bahkan ada beberapa pengikut yang merupakan mahasiswa UII turut memberikan opininya tentang susasana terkini mengenai kasus tersebut di kampus mereka. Motivasi Lambe Turah dalam mengangkat berita ini adalah agar para pelaku segera ditangkap dan diberi hukuman yang seberat-beratnya karena telah mencoreng dunia pendidikan pada umumnya, dan dunia pencinta alam pada khususnya. Sangat tragis sekali, mengingat embel-embel "pencinta" pada nama lembaganya namun, tidak memiliki rasa cinta pada sesama manusia.

\section{Analisis Meso Pemberitaan "Waspada} Komplotan Pencopet Handphone Kelas Kakap" dan "Kasus Kekerasan Mapala UII Yogyakarta"

Lambe Turah adalah salah satu nama yang sedang ramai dibicarakan di dunia maya, baik oleh para netizen ataupun media masa. Tidak jarang para netizen menilai informasi yang disuguhkan akun ini jauh lebih cepat dibanding media lainnya. Pasalnya akun sosial media ini kadang memposting sesuatu yang sangat kontroversial dengan menyerang salah satu pihak dengan berbagai foto dan video yang dijadikan buktinya. Lambe Turah sendiri adalah dua kata dalam bahasa Jawa, lambe artinya bibir dan turah artinya sisa atau kelebihan, jadi lambe turah adalah bibir berlebihan atau biang gosip, biang berita, tukang menambah-nambahkan kabar berita (seperti media). 
Berita-berita yang diposting akun Instagram Lambe Turah pun sebagian besar dari netizen. Berdasarkan hasil wawancara penyanyi Anji dengan admin Lambe Turah yang diposting di akun YouTube sang penyanyi, dapat dikatakan bahwa Lambe Turah itu sudah menjadi akun infotainment dari netizen untuk netizen. Berita yang dikirm oleh netizen ke Lambe Turah dicross check lagi kemudian bila bukti-bukti pendukung sudah cukup, maka akan dianggap layak posting. Namun, tidak semua berita kiriman yang diterima admin Lambe Turah ini diunggah menjadi postingan di Instagram. Admin harus memilah terlebih dahulu mana yang layak untuk diberitakan dan diketahui bersama. Fokus mereka adalah berita yang sedang hangat saja atau berita yang belum diketahui masyarakat.

Berdasarkan uraian di atas dapat dikatakan bahwa Lambe Turah sangat berperan dalam mempengaruhi opini masyarakat Indonesia. Akun gosip Lambe Turah merupakan akun gosip yang berpengaruh di Indonesia karena memiliki banyak fans, pengikut atau followers. Followers akun Lambe Turah juga dikenal militan, loyal dan aktif memberikan tanggapan. Rangkaian postingan berita di akun Instagram Lambe Turah bukan rangkaian yang berdiri sendiri, tetapi menyerupai rangkaian institusional yang melibatkan banyak informan.Realisasi teks berita yang dihasilkan Lambe Turah dalam setiap pemberitaan dinilai selaras dengan motto yang diembannya yaitu, Bukan Akun Hater/Fanbase. No Pic=Hoax. Gosip adalah Fakta yang Tertunda.Teori tiga dimensi AWK Norman Fairclough dapat membongkar bagaimana ideologi yang dibawa Lambe Turah dan dan bagaiman ideologi itu dapat memengaruhi opini masyarakat.

\section{PENUTUP}

\section{Simpulan}

Hasil analisis teks berita menunjukkan bahwa aspek kebahasaan diksi, penggunaan kalimat, dan pemilihan sumber dalam kutipan langsung yang digunakan Lambe Turah, telah menempatkan tema pemberitaan sebagai sebuah gerakan netizen, dari netizen dan untuk netizen. Dari segi aspek kewacanaan, Lambe Turah yang memiliki banyak pengikut dan dekat dengan berbagai kalangan, memiliki akses untuk mengangkat berita-berita yang sekiranya membutuhkan banyak tanggapan dari masyarakat agar segera ditangani. Sudah banyak berita-berita yang diangkat Lambe Turah yang mendapat perhatian masyarakat dan tidak lama setelahnya segera diselesaikan oleh pihak terkait.

Dari segi praktik sosial (analisis meso), Lambe Turah sangat berperan dalam mempengaruhi opini masyarakat Indonesia. Kebanyakan isu yang dibingkai dalam postingan Lambe Turah adalah perspektif baik versus jahat. Rangkaian postingan berita di akun Instagram Lambe Turah bukan rangkaian yang berdiri sendiri, tetapi meyerupai rangkaian institusional yang melibatkan banyak informan. 


\section{DAFTAR PUSTAKA}

Badara, Aris. 2012. Analisis Wacana: Teori, Metode, dan Penerapan Pada Wacana Media. Jakarta: Kencana Prenada Media Group.

Bungin, Burhan. 2003. Analisis Data Penelitian Kualitatif . Jakarta: PT Raja Grafindo Persada.

Darma, Yoce Aliah. 2009. Analisis Wacana Kritis. Bandung: Yrama Widya.

Devi, Paramitha. 2010. Infotainment. http://paramithadevidegreece.blogspot.co.id/2010/06/infotainm ent.html. Diakses tanggal 3 Maret 2017.

Eriyanto. 2001. Analisis Wacana Kritis Pengantar Analisis Teks Media. Yogyakarta: PT. LkiS Pelangi Aksara.

Fairclough, Norman. 1992. Introduction: Critical Language Awareness. New York: Longman.

Analysis. London: Longman.

Faturrohaman, Muhammad Nurdin. 2014. Penemu Pendiri Instagram-Kevin Systrom dan Mike Krieger. https://blogpenemu.blogspot.co.id/2014/10 /penemu-pendiri-instagram-kevinsystrom-dan-mike-krieger.html. Diakses tanggal 3 Maret 2017.

Firdaus, Winci. 2011. Metafora dalam Berita Produk China pada Surat Kabar Media Indonesia dan Kompas: Analisis Wacana Kritis. Balai Bahasa Banda Aceh: Kekelpot Jurnal Ilmiah Bahasa, volume 7, halaman 9-17.

Littlejohn Stephen dan Foss, Karen A. 2009. Teori Komunikasi - Theory of Human Communication. (Terjemahan Mohammad Hamdan). Jakarta: Salemba: Humanika.
Naresyach, Muhammad Arrighy. 2014. Etika dan Kode Etik Menulis di Media Sosial. http://softskillarrighy.blogspot.co.id/2014/ 10/etika-dan-kode-etik-menulis-dimedia.html. Diakses tanggal 3 Maret 2017.

Nastiti, Aulia. 2012. Mengupas Tayangan Infotainment dari Kerangka Industri Media.https://www.scribd.com/doc/91799 496/Mengupas-Tayangan-Infotainmentdari Kerangka-Industri-Media) diakses tanggal 3 Maret 2017.

Nugroho, Bimo, Teguh Imawan dkk. 2005. Infotainment. Jakarta: Komisi Penyiaran Indonesia.

Pathia, Laelatul. 2014. Analisis Wacana Kritis dalam Bahasa Media Jejaring Sosial (Studi Penggunaan Bahasa Akun Twitter @UINSK sebagai Akun Lembaga UIN Sunan Kalijaga Yogyakarta Periode Desember 2013-Februari 2014).Skripsi UIN Yogyakarta.Program Studi Ilmu Komunikasi dan Humaniora: UIN Yogyakarta.

Sudaryanto. 1992. Metode dan Aneka Tehnik Analisis Bahasa ( Pengantar Penelitian Wahana Kebudayaan secara Linguistik). Yogyakarta : Duta Wacana University Press.

Syamsul M. Romli, Asep. 2012. Jurnalistik Online. Bandung: Nuansa Cendikia.

Wodak, Ruth. 1997. "Critical Discourse Analysis" dalam Teun Van Dijk (ed.) Discourse as Sosial Interaction: Discourse Studies a Multidisciplinary Introduction, Vol 2. London: Sage Publication.

https://www.kontras.org/data/SURAT\%20EDA RAN\%20KAPOLRI\%20MENGENAI\%2 OPENANGANAN\%20UJARAN\%20KEB ENCIAN.pdf 
Telaga Bahasa, Vol. 6, No. 2, Juni 2018: 369-386 